\title{
Online courses offered in Brazil: mapping the latest years' context
}

\section{Machado de Campos, Silvia Regina ${ }^{\mathrm{a}}$; Henriques, Roberto ${ }^{\mathrm{a}}$ and Yanaze, Mitsuru Higuchi $^{\text {b }}$}

${ }^{a}$ Information Management School (IMS), Universidade Nova de Lisboa, Portugal, ${ }^{b}$ Escola de Comunicações e Artes (ECA) da Universidade de São Paulo (USP), Brazil.

\begin{abstract}
This paper aims to map the supply of MOOCs in Brazil, starting from the Godwin-Jones' assumption that "MOOCs are neither open nor massive, but often regular online simply courses that have been re-branded" (GodwinJones, 2014). At the same time, it approaches the Brazilian context, through an exploratory and descriptive study, based on a qualitative and inductive research strategy, divided into two main phases: the first step maps the MOOCS offered by Coursera and Veduca portals, and the ones delivered by the higher education institutions (HEIs). In contrast, the second phase compares the evolution of a different category of online courses, other than MOOCS: the accredited online undergraduate courses offered by HEIs, through the longitudinal analysis of data from the Census of Higher Education, between the years 2008 and 2013. It concludes that the courses offered are not regular online simply re-branded ones, as there are different provisions, but they are subject to the Brazilian particular regulatory conditions.
\end{abstract}

Keywords: Massive Open Online Courses; MOOC; E-learning; Undergraduate Courses; Higher Education. 


\section{Introduction}

The term MOOC was first used in 2008 (Thille, 2014) but only in 2011, it became visible when US elite universities began to offer open and distance free courses. Greater attention was given to this type of course when institutions such as Stanford, MIT, and Harvard began to offer them through its platforms - Coursera, MITX, EDX, respectively. However, the prominence of MOOCs is the result of growing enrollment, the aggressive stance by the prestigious universities, and the increase of the investment by foundations and other stakeholders (Thille, 2014).

In Brazil, the first e-learning courses were offered by correspondence, via TV or primitive forms. The first MOOC initiative was launched by the Universidade Estadual Paulista "Julio de Mesquita Filho" in 2012 and titled "Open Unesp"b (Wikipedia, 2015). Moreover, in 2013, MOOCs were launched by the University of São Paulo (USP), in partnership with the Brazilian portal Veduca (Veduca, 2015). The MOOCs have specific characteristics. It allows the entry of a vast number of students. The courses are free; usually offer no diploma, only one conclusion certification; and vary in their educational purposes, philosophies and the technological resources used (Thille, 2014). This model has also been evolving to different stages of development, similarly to what has occurred in other countries, and there are various types of courses with varying degrees of openness, course fees, qualification requirements (Commission, 2013), credit-earning, and models of delivery (UK, 2013).

Considering that the studies don't take into account how MOOCs are being used in Brazil, this paper aims to map the supply of Massive Open Online Courses - MOOCs in the country, starting from the Godwin-Jones' assumption that "MOOCs are neither open nor massive, but often regular online simply courses that have been re-branded" (GodwinJones, 2014). At the same time, it approaches the Brazilian context, concluding that its courses are not regular online simply re-branded ones, as there are different provisions, subject to the Brazilian particular regulatory conditions.

This paper presents an exploratory and descriptive study, based on a qualitative and inductive research strategy, divided into two main phases. The first step maps the MOOCs offered by Coursera (Coursera, 2015) and Veduca (Veduca, 2015) portals, and the ones delivered by the higher education institutions (HEIs) precursors of such offer in Brazil. In contrast, the second phase compares the evolution of a different category of online courses, other than MOOCS: the accredited online undergraduate courses offered by Higher Education Institutions - HEIs, through the longitudinal analysis of data from the Census of

\footnotetext{
${ }^{\mathrm{b}}$ Universidade Aberta
} 
Higher Education, an annual survey conducted by the National Institute for Research and Educational Studies Anísio Teixeira - INEP, between the years 2008 and 2013.

The remainder is organized as follows. The next section presents the MOOCs' offer in the Brazilian Context and the Discussions. The last section points out the Preliminary Conclusions.

\section{The MOOCs in the Brazilian Context}

The first phase developed research in the two MOOCS portals in Brazil (Coursera, 2015; Veduca, 2015). From both platforms, the courses offered by higher education institutions were selected, where only two Brazilian HEIs were identified: State University of Campinas - Unicamp and the University of São Paulo - USP (Table 1), which represented $2.15 \%$ of all related partners $(\mathrm{N}=139)$ from 28 countries (Coursera, 2015).

Table 1. MOOCs offered by Coursera through HEIs

\begin{tabular}{ll}
\hline & \multicolumn{1}{c}{ MOOC } \\
\hline & How to create 2D games for iPhone and iPad \\
\cline { 2 - 2 } How to enhance and monetize the app for iOS \\
\cline { 2 - 2 } The Entrepreneurship and Entrepreneur Skills \\
\cline { 2 - 2 } Creating and publishing application for iPhone and iPad in the App Store \\
\cline { 2 - 2 } & How to create an iPhone app \\
\cline { 2 - 2 } & Creating applications with multiple screens for iPhone and iPad \\
& Digital Signal Processing - Sampling \\
\hline & Pluralities in Brazilian Portuguese \\
\hline Big Data in Health in Brazil \\
\hline
\end{tabular}

The classes are free and in reduced number (Table 1). From a total of 1,484 $(\mathrm{N}=100 \%)$, MOOCS provided by the platform, only $12(0.8 \%)$ are of Brazilian HEIs. Moreover, from this total, nine $(0.6 \%)$ were being offered at the time of this research, which was based on documentary research in the virtual environment, from November to December 2015. The portal Veduca (Veduca, 2015), in turn, includes different categories of courses: for free, 
$\mathrm{MBAs}^{\mathrm{c}}$ and extension; and comprise various areas of knowledge. Seven Brazilian HEIs provide online courses, but MOOCs are offered by three of them (Table 2).

Table 2. MOOCs offered by Veduca Platform

\begin{tabular}{cc}
\hline HEI & MOOC \\
\hline USP & Basic Physics \\
\hline UNB & Bioenergetics \\
\hline Unisinos & Brazilian Sign Language - Libras \\
\hline & Source Veduca, 2015.
\end{tabular}

The next phase mapped the current offer of the two public HEIs, recognized as the MOOC precursors in Brazil: UNESP and USP. According to UNESP (UNESP, 2015), and in particular, to the Open University, the courses are organized by areas of knowledge (Table 3) and are free of charge. Despite the fact that the courses intended to be MOOCs, there is no reference to MOOC terminology neither in the name of the courses nor the web portal of the institution.

Table 3. MOOCs offered by the Open University, UNESP

\begin{tabular}{|c|c|}
\hline \multicolumn{2}{|c|}{ Knowledge Area $\quad$ MOOCs } \\
\hline Biological & Content and Teaching of Physical Education \\
\hline \multirow{2}{*}{ Exact } & Numerical Calculus roots functions - method of Bisection \\
\hline & Machinery Diagnostic Tools \\
\hline \multirow{16}{*}{ Human } & The Education Basis and Guidelines Law \\
\hline & Public communication, citizenship and digital democracy \\
\hline & Literacy Content and Curriculum \\
\hline & Content and Teaching Arts \\
\hline & Content and Teaching of Science and Health \\
\hline & Content and Teaching of Geography \\
\hline & Content and Teaching of History \\
\hline & Content and didactics of Portuguese Language and Literature \\
\hline & $\begin{array}{l}\text { Course Assistive Technology, Projects, and accessibility. Promoting } \\
\text { School Inclusion }\end{array}$ \\
\hline & General Didactics \\
\hline & Administrative law \\
\hline & Education and Language: Early Childhood Education \\
\hline & Education and Society \\
\hline & Inclusive and Special Education \\
\hline & Children's education: curriculum approaches \\
\hline & Early Childhood Education: Different forms of Expressive and \\
\hline
\end{tabular}

${ }^{\mathrm{c}}$ Master in Business Administration 


\begin{tabular}{ll}
\hline Communicative Languages \\
Ethics and Citizenship \\
\hline Philosophy of Education \\
\hline Children's Education Foundations and Principles \\
\hline History of Education \\
\hline Introduction to Scientific Research \\
\hline Educational politics \\
\hline Educational Psychology \\
\hline Relations and procedures in the Workplace \\
\hline Sociology of Education \\
\multicolumn{1}{c}{ Source: Portal UNESP, 2015.}
\end{tabular}

According to the USP web portal (USP, 2015), the identified courses are listed in Table 4 and include different categories, other than MOOCs. As already seen above, in the USP web portal there are no explicit references to MOOC terminology to the courses offered. Both are free.

Table 4. Courses offered by USP

\begin{tabular}{ll}
\hline Undergraduate & Blended undergraduate course in Sciences \\
\hline Specialization & Specialization in Ethics, Values, and Health in School \\
\cline { 2 - 2 } & Motor Learning \\
\hline Update & Food and Agribusiness Marketing \\
\hline Diffusion & Introduction to Education Design \\
\hline & Source: Portal USP, 2015.
\end{tabular}

The second phase of the study maps the supply of online undergraduate courses in Brazil, 2008-2013, based on the Census of Higher Education (INEP, 2013). It adopted the year 2013 as a reference for being the last to official data available and the 2008 year for a comparative 5-year analysis. This part of the study had the intention to check if the Godwin-Jones' assumption could be confirmed or rejected, by evaluating the online courses offered by the HEIs in the country and compare them to the MOOCs category. The results are presented below.

In Brazil, for decades, there has been an increase in the number of HEIs, with a corresponding rise in the number of courses and places offered. From 2008 to 2013, this represents an increase of around $6 \%$. In the same period, regarding the accredited online undergraduate courses, it can be observed an increase in the number of classes offered and students enrolled, but a decrease in the number of places offered, as shown in Figure 1. 
In this period, the number of undergraduate courses almost doubled. The number of students enrolled in 2013 also had a significant increase compared to 2008, indicating a potential interest in e-learning. However, only $18,75 \%$ of all the country's student body is enrolled in online undergraduate courses. The number of places offered is already greater than the number of pupils enrolled, pointing to a vast number of vacant (available) places.

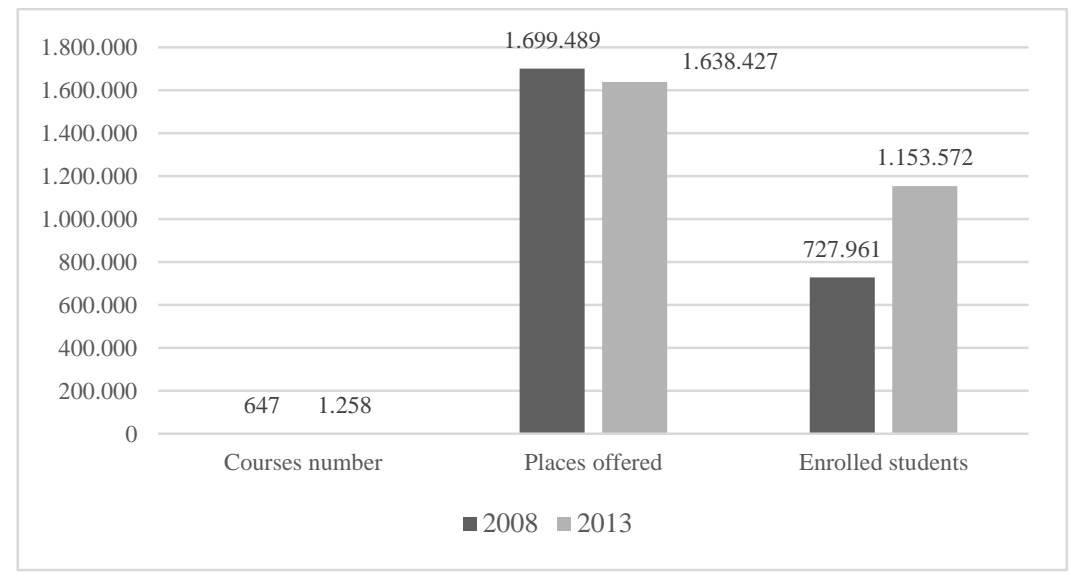

Figure 1. Number of courses, places offered and enrolled students. Source: MEC, INEP, 2013.

The vast majority of online courses offered, according to the Census of Higher Education (INEP, 2013), are in the areas of education; Social Sciences, Business, and Law; followed later by others, as demonstrated in Figure 2.

Taking into account the OCDE main areas, there is more receptivity to the courses offered in the Humanities and Social Sciences, although such courses are still small in gross numbers if compared to the total traditional undergraduate courses $(\mathrm{N}=30.791)$ provided in the country. 


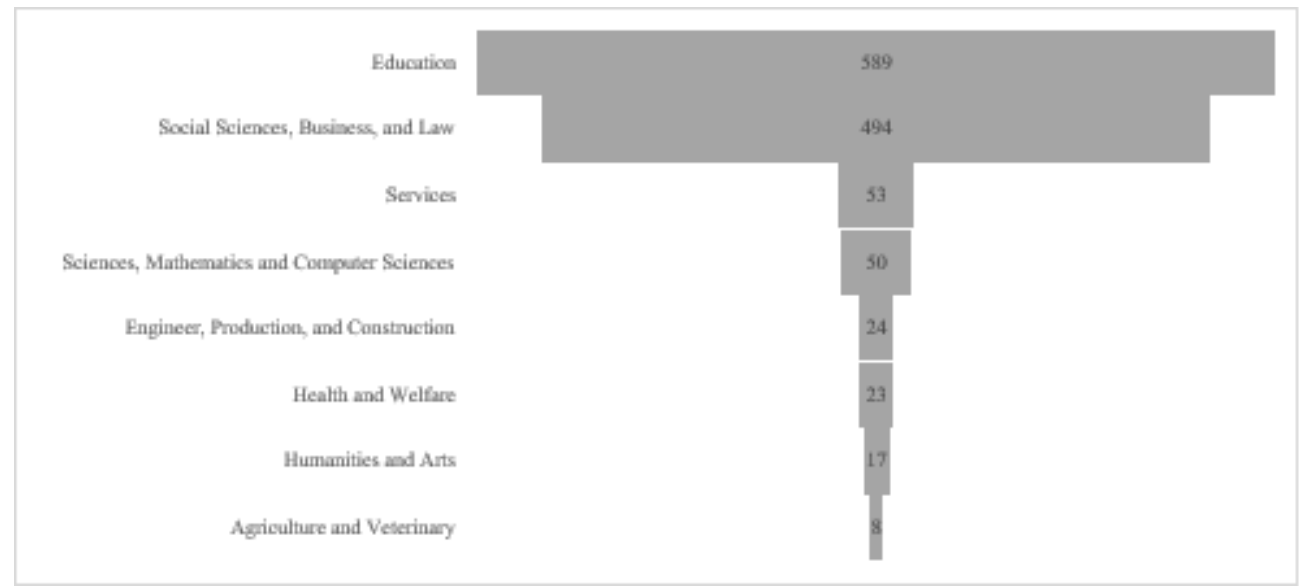

Figure 2. Online courses offered, OCDE main areas, 2013. Source: MEC, INEP, 2013.

\section{Overview}

Unlike MOOCs that early in its offer were free, undue courses and did not provide certification; in Brazil, the undergraduate online or blended courses are from a different provision category, offered only by accredited public or private higher educational institutions. They can be free or paid, depending on the HEI category - if public or private. These courses depend on prior accreditation by the Ministry of Education, which regulates, supervises and evaluates the institutions of higher education and its undergraduate courses (Educação, 2007; Selingo, 2014 ). Many of the online undergraduate courses, according to Brazilian legislation (Educação, 2007; Selingo, 2014 ), though not obtain the title of MOOC or use its terminology, may have a high number of places offered, which means they can be massive; also can be free; but are not "open" in the MOOCs context, cause the students obligatory need to have concluded previous education.

Besides the fact that some countries already discuss the possibility of credit-earning MOOCs courses, in Brazil, they comprised, exclusively, the courses without accreditation and delivered through third platforms. Including the courses offered by HEIs, which are open about their content availability to any person; are modest in quantity, but can rely on payment for the issuance of a certificate, and are delivered through Coursera and Veduca platforms. Their "denominations" also are entirely different from those accredited courses offered in online or blended mode by HEIs (Tables 1, 2, 3, 4). Concerning the assumption stated by Godwin-Jones (2014), in Brazil, the MOOCs are open and massive courses, but are not regular online courses that have been re-branded, because the "regular online courses" are the accredited ones. It is important to state that, besides the limited number of 
MOOCs offered in the country, even by HEIs, it is highly recommended to evaluate the number of students enrolled, to map its massive extent. Besides that, the courses have different publics as a target.

Another interesting conclusion depicted from this research is related to knowledge areas of the courses offered (Figure 2) which are Education; and Social Sciences, Business and Law despite the 'apparent' resistance of Social Sciences area to the use of technological resources, as shown by the literature (Education, 2013; Reichard 2015). There is no much overlapping concerning the topics dealt, despite the differences between the MOOCs and the online undergraduate courses. Apparently, this situation can be justified by the government policy of training of the teaching workforce, specially, in basic education.

It becomes necessary to think about new ways of offering courses in a connected society in which new paradigms guide the communication practices, looking out at present as a promise of renewal of knowledge, motivated by new ways of knowledge formation, enabled by digital networking environment (Burdick, 2012). At the same time, it is necessary to discuss that, as an essential part of the societal role of universities is to facilitate lifelong learning, regardless of age, place of residence and life situation. Flexible education is a core term in this context as it deliveries mean education that can be carried out regardless of time and place; that require less presence on campus.

\section{References}

Burdick, A. D., Johanna; Lunenfeld, Peter; Presner, Todd; Schnapp, Jeffrey. (2012). Digital_Humanities

Commission, M. (2013). Time for MOOCs: MOOC Commission sub-report. Retrieved from https://www.regjeringen.no/globalassets/upload/KD/Time for_MOOCs.pdf:

Coursera. (2015). Retrieved from https://pt.coursera.org/browse/

PORTARIA NORMATIVA N o 2, DE 10 DE JANEIRO DE 2007 - Dispõe sobre os procedimentos de regulação e avaliação da educação superior na modalidade a

distância., (2007).

Education, T. C. o. H. (2013). 'An Open Letter to Professor Michael Sandel From the Philosophy Department at San Jose State U.'. Retrieved from http://chronicle.com/article/The-Document-an-Open-Letter/138937/

Godwin-Jones, R. (2014). Emerging Technologies. Global reach and local practice: The promise of MOOCS. Language Learning \& Technology, 18(3), 5-15.

INEP, I. N. d. E. e. P. E. A. T.-. (2013). Censo da Educação Superior. Retrieved from <http://portal.inep.gov.br/basica-levantamentos-microdados $>$

Reichard , C. (2015). MOOCs face challenges in teaching humanities. Retrieved from http://www.stanforddaily.com/2013/06/04/moocs-face-challenges-in-teachinghumanities/\# 
Selingo, J. J. (2014 ). Demystifying the MOOC. Retrieved from http://www.nytimes.com/2014/11/02/education/edlife/demystifying-themooc.html? rr=0

Thille, C. (2014). MOOCs and Technology to Advance Learning and Learning Research. Ubiquity Symposium. doi:10.1145/2601337

UK, U. (2013). Massive Open Online Courses. Retrieved from http://www.universitiesuk.ac.uk/highereducation/Documents/2013/MassiveOpenOnline Courses.pdf

UNESP, U. E. P. J. d. M. F. (2015). Universidade Aberta. Retrieved from http://www.unesp.br/unespaberta

USP, U. d. S. P. (2015). Retrieved from http://www5.usp.br/ensino/educacao-a-distancia/ Veduca. (2015). Veduca. Retrieved from http://www.veduca.com.br/

Wikipedia. (2015). MOOCS. Retrieved from https://pt.wikipedia.org/wiki/MOOC 